\title{
A model of woody-herbaceous biomass rela- tionships in eucalypt and mesquite communities
}

\author{
JOSEPH C. SCANLAN
}

\begin{abstract}
Author is principal pasture agronomist, Queensland Department of Primary Industries, Charters Towers, Australia 4820. Data from Texas were collected while the author was a postgraduate student in Range Science Department, Texas A\&M University, College Station, Texas.
\end{abstract}

\begin{abstract}
A spatial simulation model was developed to examine the community-level relationships between woody overstory and herbaceous understory. The influences of individual trees on herbaceous understory were aggregated into stimulatory and competitive effects which were represented as indices. The net index at a particular point on the landscape was calculated by multiplying the indices of all trees having an effect at that point. Simulated sampling of computer-generated communities (calculating the net index at a number of randomly selected points) enabled the herbaceous production to be estimated for communities of defined tree density and size. The model was parameterized for eucalypt (Eucalyptus crebra F. Muell.) communities in northeastern Australia and for honey mesquite (Prosopis glandulosa var glandulosa Torr.)-mixed brush areas in southwestern U.S.A.

When a net competitive effect exists around individual trees, a negative curvilinear relationship between herbaceous yield and tree density was observed in the simulations. If stimulatory effects dominate at the individual tree level, herbaceous yield at the community level was highest at intermediate tree densities. Thus the extremes of relationships seen in the literature can be reproduced simply by altering the relative strength of stimulation and competition in this model. The model can be used to examine the change in herbaceous yield at the community level following manipulation of woody cover.
\end{abstract}

\section{Key Words: Prosopis glandulosa, Eucalyptus crebra, overstory-} understory, simulation

The level of animal production in savannas and woodlands is greatly influenced by the balance between woody and herbaceous vegetation (Clary 1975). Many relationships between herbaceous production and woody cover have been noted throughout the world. These range from a negative exponential decline in herbaceous yield as tree basal area increases (Beale 1973), to a linear decline as tree density increases (Walker et al. 1986a), to an initial increase at low canopy cover followed by a decrease as cover increases further (Scifres et al. 1982). The last pattern reflects herbaceous stimulation provided by trees possibly through influences on soil nutrients, rainfall redistribution, and microclimate changes and their competition for water, light, and nutrients. Such a variety of responses provides a challenge to describe the underlying interaction between overstory and understory at the community level.

The objective of this paper is to present an empirical model

\footnotetext{
Research was in part funded by Australian Meat and Live-stock Research and Development Corporation. The author wishes to thank Dr. C.J. Scifres and Dr. G.M. McKeon for encouragement and suggestions during development of this model.

Manuscript accepted 31 March 1991.
}

based on the effects of individual trees on herbaceous vegetation which addresses the woody-herbaceous relationship at the community level. Model validation will be provided for 5 field sites ( 3 eucalypt (Eucalyptus crebra F. Muell) in northeastern Australia and 2 honey mesquite (Prosopis glandulosa var glandulosa Torr.) in southwestern U.S.A.).

\section{Method}

\section{Model Development}

My model is based on ideas proposed by Wu et al. (1985) and Walker et al. (1986b). They developed the concept of an ecological field to explain the interactions among neighboring plants located at a distance from each other. They use interference to describe the influence of a plant on its neighbor's environment through resource competition and less direct interaction. The degree of interference decreases as the distance from the tree increases. Their model included separate effects of the crown, trunk, and roots of trees on other vegetation. For my model, these effects were amalgamated into those factors which tended to increase herbaceous yield potential (stimulation) and those that decreased this potential (competition).

Using this general approach, the net effect of several trees at a point can be simulated. This information on an individual tree basis can be used to predict responses at the community level.

\section{Model Description}

At any point (i) on the landscape, the herbaceous layer may be influenced by competitive (C) and stimulatory (S) forces from many individual trees $(w)$. The net effect $(N)$ is the product of these competitive and stimulatory effects. This is represented by Eq. 1 .

$$
\mathrm{N}_{\mathrm{i}}=\mathrm{C}_{\mathrm{i} \text { (total) }} * \mathrm{~S}_{\mathrm{i} \text { (total) }}
$$

Eq. 1

where

$$
\begin{aligned}
& \mathrm{C}_{\mathrm{i}(\text { total })}=\left[\mathrm{C}_{\mathrm{i}(1)}{ }^{*} \mathrm{C}_{\mathrm{i}(2)}{ }^{*} \ldots{ }^{*} \mathrm{C}_{\mathrm{i}(\mathrm{w})}\right] \\
& \mathrm{S}_{\mathrm{i} \text { (total })}=\left[\mathrm{S}_{\mathrm{i}(1)} \mathrm{S}_{\mathrm{i}(2)}{ }^{*} \ldots{ }^{*} \mathrm{C}_{\mathrm{i}(\mathrm{w})}\right] \\
& \text { and } \mathrm{N}_{\mathrm{i}}>0 ; 0<\mathrm{C}_{\mathrm{i}(\text { total })}<1 ; 1<\mathrm{S}_{\mathrm{i} \text { (total })}<\mathrm{S}_{\max }
\end{aligned}
$$

$S_{\max }$ is a function of the growth potential of herbaceous species and the abiotic influences on growth and for the communities studied here, $S_{\max }$ was set to 2.5 . The indices are scaled such that when $N=1$ the herbaceous production is equivalent to that in the open $\left(\mathrm{Y}_{\text {open }}\right)$. The herbaceous yield at any point on the landscape is given by Eq. 2.

$$
\mathbf{Y}_{\mathbf{i}}=\mathbf{Y}_{\text {open }} * \mathbf{N}_{\mathbf{i}}
$$

Eq. 2

Within the model, trees are randomly distributed within a simulated plot area of $60 \mathrm{~m} \times 60 \mathrm{~m}$. Nonrandom distributions could be incorporated using the approach of Wu et al. (1987). Twenty-five sampling points were then randomly selected in the central $40 \mathrm{~m} X$ $40 \mathrm{~m}$ area. At each point, $C_{\mathrm{i}}$ and $S_{\mathrm{i}}$ for each tree were calculated. 
The net index, $\mathrm{N}_{\mathrm{i}}$, was then calculated (Eq. 1) and a simulated yield calculated at that point (Eq. 2).

A flexible equation with interpretable parameters was required to describe the changes in $\mathrm{C}$ and $\mathrm{S}$ with distance from the tree. For this purpose, Eqs. 3 and 4 were chosen.

$$
S_{i}=1+S_{0}{ }^{*} r_{s}{ }^{n s} /\left(r_{s}{ }^{n s}+d_{s}{ }^{n s}\right)
$$

where

$\mathrm{S}_{0}$ is the stimulation index at tree-trunk and is maximum at that point $\left(\mathrm{S}_{0}>1\right)$;

$r_{s}$ is the distance from the tree at which the $S_{i}=0.5^{*}\left(S_{0}-1\right)+1$ (i.e. where the stimulation effect is half of the maximum value);

ns is a parameter which influences the slope of the curve away from the tree trunk;

and $d_{s}$ is distance from the tree to sampling position.

Similarly, for competition,

$$
\mathrm{C}_{\mathrm{i}}=1-\left(1-\mathrm{C}_{0}\right) * \mathrm{r}_{\mathrm{c}}{ }^{\mathrm{nc}} /\left(\mathrm{r}_{\mathrm{c}}{ }^{\mathrm{nc}}+\mathrm{d}_{\mathrm{c}}{ }^{\mathrm{nc}}\right)
$$

Eq. 4

where

$\mathrm{C}_{0}$ is the competition index at the tree-trunk; $0<\mathrm{C}_{0}<1$ (small $\mathrm{C}_{0}$

$=$ large effect);

$r_{c}$ is distance from the tree at which $C_{i}=0.5^{*}\left(1-C_{0}\right)$;

$n c$ is a parameter which influences the slope of the curve away

from the tree;

and $d_{c}$ is distance from the tree to sampling position.

Thus the indices can be fully described by (1) maximum effect at the tree trunk ( $\mathrm{S}$ is at a maximum; $\mathrm{C}$ value is a minimum); (2) the distance away from the trunk that the effect is half of the maximum; and (3) the pattern of influence of the tree on the index with increasing distance from the tree. If nc or $\mathrm{ns}$ is low, the effect declines rapidly with distance from the tree trunk; if nc or ns is large, the effect remains "constant" for some distance from the tree and then declines rapidly to the value for open areas (see Fig. 1).

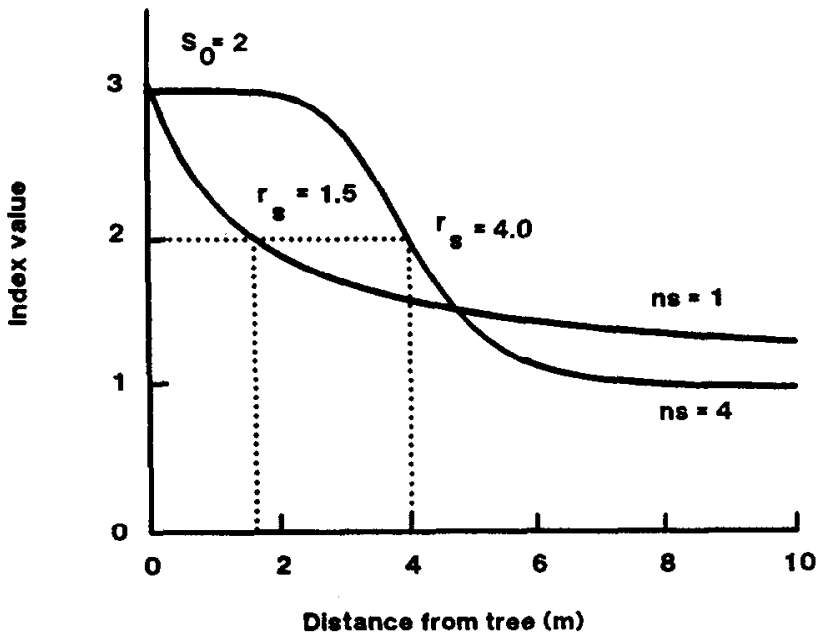

Fig. 1. Examples of the stimulation index showing the influence of the shape parameter (ns) on the pattern of change with increasing distance from the tree.

\section{Model Parameterization}

\section{Eucalypt Size}

The parameterization site was located about $100 \mathrm{~km}$ west of Rockhampton, Australia $\left(150^{\circ} 30^{\prime} \mathrm{E}, 2^{\circ} 22^{\prime} \mathrm{S}\right)$ on undulating areas within the black speargrass ( Heteropogon contortus (L.) Beauv. ex Roemer \& Schultes) vegetation community (Weston et al. 1981). The main woody species was Eucalyptus crebra with herbaceous vegetation dominated by $\mathrm{C}_{4}$ grasses including black speargrass, Aristida spp. (L.), Bothriochloa spp. (C.E. Hubbard) and Eragrostis spp. (Wolf). The climate of the area is subtropical with warm winters and hot summers. The mean annual rainfall is about 730 $\mathrm{mm}$ with $75 \%$ received during the November to April summer period. The soil consists of a loamy-textured $A$ horizon with a conspicuously bleached $A_{2}$ horizon over a sodic clay $B$ horizon at $40 \mathrm{~cm}$ (a natrustalf) and site slope was less than 5\%.

Within the experimental area, 20 trees (10 pairs) each of 3 size classes (shrubs, 10 to $15 \mathrm{~cm}$ basal diameter; small trees, 15 to $30 \mathrm{~cm}$ basal diameter; and large trees, 30 to $50 \mathrm{~cm}$ diameter) were selected. One of each pair of trees was killed with herbicide. Two growing seasons after tree treatment, herbaceous biomass at $0.5,1.0$, and 2.0-m intervals from the tree trunk (for shrubs, small trees, and large trees, respectively) was determined by visually rating 5 quadrats at each location (Tothill et al. 1978). The yield response for each class is shown in Fig. 2a.

(a)

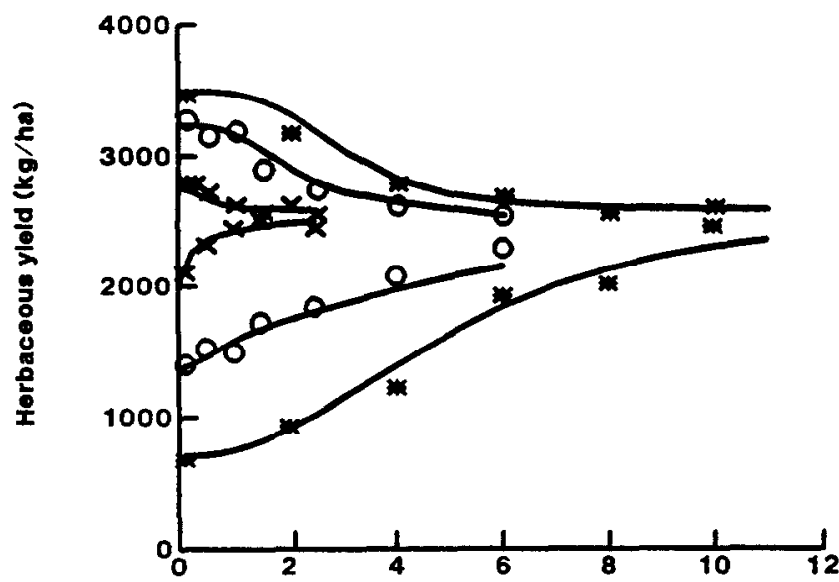

Distance from tree $(\mathrm{m})$

(b)

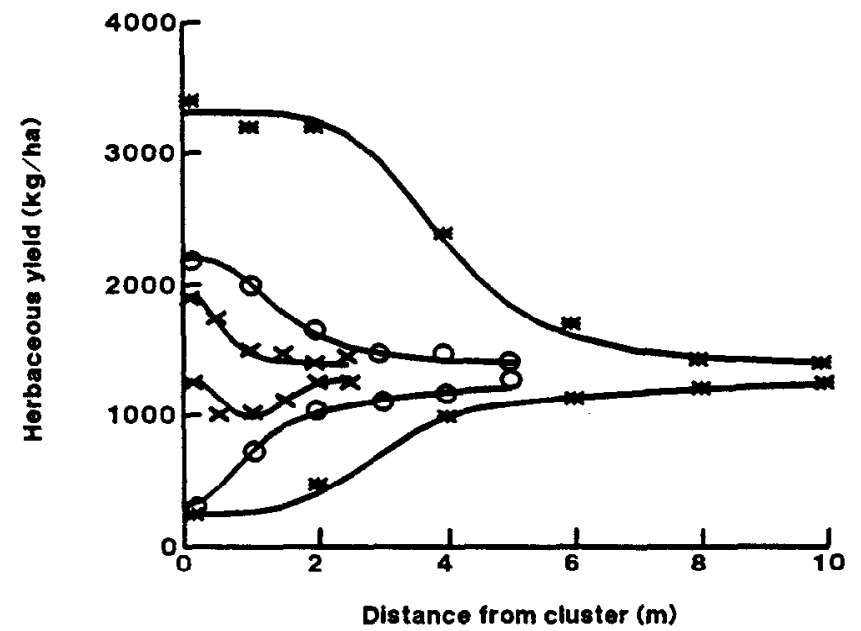

Fig. 2. Herbaceous biomass around individual live and dead (a) trees ( ${ }^{*}$ ), small trees $(0)$, and shrubs $(x)$ at the eucalypt parameterization site near Rockhampton, A ustralia; and (b) shrub clusters [mature (*), developing (o) and pioneer $(x)]$ at the mesquite parameterization site near Alice, Texas. Lines are fitted lines using parameters from Tables 1 and 2 , respectively.

From these curves, the parameters of Eqs. 3 and 4 were determined (Table 1). $S_{0}$ was calculated as the ratio of yield beneath dead trees to the yield of open areas. This is only an approximation of the actual stimulatory effect of live trees. It overestimates $S_{0}$ for live trees as part of the stimulation would be due to the release of nutrient following the death of the tree, and underestimates $S_{0}$ 
Table 1. Parameters for equations 3 and 4 used in the simulation of herbaceous yield in eucalypt communities near Rockhampton, Australia.

\begin{tabular}{|c|c|c|c|c|c|c|}
\hline \multirow[b]{2}{*}{ Parameter } & \multicolumn{2}{|c|}{ Large trees } & \multicolumn{2}{|c|}{ Small trees } & \multicolumn{2}{|c|}{ Shrubs } \\
\hline & Dead & Live & Dead & Live & Dead & Live \\
\hline $\begin{array}{l}\text { So } \\
\text { ns } \\
r_{\text {s }}\end{array}$ & $\begin{array}{l}0.35 \\
3.5 \\
3.0\end{array}$ & $\begin{array}{l}0.35 \\
3.5 \\
3.0\end{array}$ & $\begin{array}{l}0.25 \\
3.0 \\
2.0\end{array}$ & $\begin{array}{l}0.25 \\
3.0 \\
2.0\end{array}$ & $\begin{array}{l}0.07 \\
2.0 \\
0.5\end{array}$ & $\begin{array}{l}0.07 \\
2.0 \\
0.5\end{array}$ \\
\hline $\begin{array}{l}\mathrm{C}_{0} \\
\mathrm{nc} \\
\mathrm{r}_{\mathrm{c}}\end{array}$ & $\begin{array}{l}\text { na' } \\
\text { na } \\
\text { na }\end{array}$ & $\begin{array}{l}0.21 \\
2.5 \\
5.0\end{array}$ & $\begin{array}{l}\text { na } \\
\text { na } \\
\text { na }\end{array}$ & $\begin{array}{l}0.42 \\
1.5 \\
3.5\end{array}$ & $\begin{array}{l}\text { na } \\
\text { na } \\
\text { na }\end{array}$ & $\begin{array}{l}0.72 \\
1.0 \\
0.4\end{array}$ \\
\hline$Y_{\text {open }}=260$ & $\mathrm{gg} / \mathrm{ha}$ & & & & & \\
\hline
\end{tabular}

Inot applicable; no competitive effect

because stimulatory effects of shade (Wilson et al. 1986) and altered microclimate are reduced by killing the tree. Under low soil nutrient conditions, however, the enhanced nutrient status and improved soil physical conditions (Dowling et al. 1986, Tiedemann and Klemmedson 1986) are likely to dominate other effects. In situations where other effects are important, another system of estimating $S_{0}$ would be required.

$\mathrm{C}_{0}$ was then estimated from the competition (trees alive) curve as $\mathrm{S}_{0} * \mathrm{C}_{0}=\mathrm{N}_{0}$ (i.e., net index at base of live tree). Other parameters were fitted by iteration until the sum of squared deviations of data points from the curves was not decreased by further changes.

\section{Mesquite Site}

The parameterization site was located on the Texas Agricultural Experiment Station, La Copita Research Area in Jim Wells County near Alice, Texas $\left(27^{\circ} 40^{\prime} \mathrm{N}, 98^{\circ} 12^{\prime} \mathrm{W}\right)$ in the eastern Rio Grande Plains of the Tamaulipian Biotic Province (Scifres and Koerth 1987). The site was a savanna parkland with discrete clusters of woody plants organized beneath mesquite (Archer et al. 1988). Herbaceous vegetation between shrub clumps was dominated by $\mathrm{C}_{4}$ grasses such as Aristida spp., Paspalum setaceum (Michx.), Texas grama (Bouteloua rigidiseta Steud.) and hooded windmillgrass (Chloris cucullata Bisch). Climate is subtropical with mild winters and hot summers. Mean annual rainfall is 680 $\mathrm{mm}$ with maxima in May and September. Soils on the study sites are fine sandy loams derived from sandstones and are classified as typic argiustolls (USDA 1975).

The central mesquite was chosen as the cluster center because this is the location from which cluster development started (Archer et al. 1989). Herbaceous samples were taken along 2 transects from the center to associated interspace. Yield was visually assessed for 3 clusters of each size class (pioneer, developing, and mature) at intervals of $0.5,1.0$, and $2.0 \mathrm{~m}$ from cluster center, respectively. At each cluster by distance position, 4 quadrats per cluster were rated. Figure $2 b$ shows the herbaceous yield around the 3 cluster classes. Model parameters were determined as for eucalypt site and are shown in Table 2.

\section{Model Validation}

Three eucalypt and 2 mesquite validation sites were set up to test the model: none of these data were used in the development of the model. All eucalypt sites were located within $100 \mathrm{~km}$ of Rockhampton on the same soil type and within the same vegetation community as the parameterization site. The validation sites (20 ha) were ungrazed (site 1 ) or lightly grazed (sites 2 and 3) communities in which a number of variable-sized plots $(0.1$ to $0.5 \mathrm{ha})$ were used to determine overstory-understory relationships in Eucalyptus communities (Scanlan and Burrows 1990). In these plots, all trees were tallied and categorized into the 3 tree size classes used at the parameterisation site (Table 3 ). Selective tree thinning was applied to site 1,18 months before sampling, whereas no tree
Table 2. Parameters for equations 3 and 4 used in the simulation of herbaceous yield in mesquite communities near Alice, Texas.

\begin{tabular}{|c|c|c|c|c|c|c|}
\hline \multirow[b]{2}{*}{ Parameter } & \multicolumn{2}{|c|}{ Mature clusters } & \multicolumn{2}{|c|}{ Developing clusters } & \multicolumn{2}{|c|}{ Pioneer cluster } \\
\hline & Dead & Live & Dead & Live & Dead & Live \\
\hline $\begin{array}{c}\mathrm{S}_{0} \\
\mathrm{~ns} \\
\mathrm{r}_{\mathrm{q}}\end{array}$ & $\begin{array}{l}1.4 \\
5.0 \\
4.0\end{array}$ & $\begin{array}{l}1.4 \\
5.0 \\
4.0\end{array}$ & $\begin{array}{l}0.6 \\
3.0 \\
1.5\end{array}$ & $\begin{array}{l}0.6 \\
3.0 \\
1.5\end{array}$ & $\begin{array}{l}0.4 \\
3.0 \\
0.6\end{array}$ & $\begin{array}{c}0.4 \\
3.0 \\
0.6\end{array}$ \\
\hline $\begin{array}{c}\mathrm{C}_{0} \\
\mathrm{nc} \\
\mathrm{r}_{\mathrm{c}}\end{array}$ & $\begin{array}{l}\text { na' } \\
\text { na } \\
\text { na }\end{array}$ & $\begin{array}{l}0.12 \\
3.5 \\
4.5\end{array}$ & $\begin{array}{l}\text { na } \\
\text { na } \\
\text { na }\end{array}$ & $\begin{array}{l}0.18 \\
2.0 \\
1.6\end{array}$ & $\begin{array}{l}\text { na } \\
\text { na } \\
\text { na }\end{array}$ & $\begin{array}{l}0.70 \\
6.0 \\
1.5\end{array}$ \\
\hline \multicolumn{7}{|c|}{$Y_{\text {open }}=1500 \mathrm{~kg} / \mathrm{ha}$} \\
\hline
\end{tabular}

Inot applicable; no competitive effect

killing had occurred recently on sites 2 and 3 . Herbaceous biomass was estimated at the end of summer (peak standing crop) by visually rating 50 quadrats per plot (Tothill et al. 1978).

For mesquite, 2 sites were set up (Table 4). Site 1 was a 20 -ha undisturbed site with 6 plots (each 1 ha) selected containing a wide range of total shrub covers. Cover was determined by measuring the canopy area of each cluster in the experimental area. Site 2 had been aerially sprayed with herbicide 15 months before sampling. Plots were established and cover measured as for site 1 . The sites were not grazed by cattle for 12 months before sampling.

\section{Simulation Methodology}

For each validation site, the woody plant data collected from the sites were entered into the model, and the appropriate parameters from Tables 1 and 2 were used. For each study using the model, 20 separate simulations (rerandomizing tree and sampling positions for each simulation) were run and the mean of the 20 simulations presented.

\section{Results}

Model output paralleled plot yield data closely for both communities (Fig. 3). Given the 2 contrasting communities, the simplification of using 3 size classes and the fact that both undisturbed and manipulated communities were represented, the model appears to be robust and have wide applicability.

The empirical model successfully predicts community level consequences of tree effects on herbaceous understory production within eucalypt and mesquite communities from a description of the effects of individual trees on understory vegetation.

\section{Shape of Overstory-Understory Curves}

It was hypothesized that the wide range of relationships between herbaceous and woody vegetation noted throughout the world could be simulated by altering model parameters in Equations. 3 and 4. A range of possible $S$ and $C$ curves around an individual tree is shown in Figure 4, giving rise to (a) net competition, and (b) net stimulation. The parameters of these curves were used to simulate the herbaceous-woody relationship on a community level (Fig. 5).

Where net competition exists, the commonly observed negative exponential relationship between herbaceous biomass and woody density is exhibited (line a in Figure 5). At the other extreme, net simulation gave rise to a curve with a maximum at 100-150 trees/ ha (line $b$ in Figure 5). The reason for the initial increase and subsequent decline with increasing tree density is that $S_{i(t o t a l)}$ can increase only until $S_{\max }$ whereas $C_{i(t o t a l)}$ can approach zero. At a point, $N=1$ if no trees are present within sufficient distance to influence the herbaceous production. As trees are "added" to the landscape, $S_{i(\text { total })}$ increases to $S_{\max }$ and $C_{i(t o t a l)}$ decreases in magni-

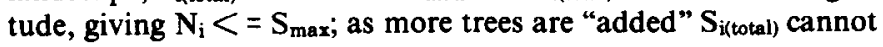


Table 3. Total density and size class composition of woody plants (before and after treatment) in eucalypt sites near Rockhampton, Australia.

\begin{tabular}{|c|c|c|c|c|c|c|c|c|}
\hline & \multirow[b]{2}{*}{ Plot } & \multirow[b]{2}{*}{ Density } & \multicolumn{3}{|c|}{ Proportion of } & \multirow[b]{2}{*}{$\begin{array}{l}\text { Proportion } \\
\text { killed }\end{array}$} & \multirow[b]{2}{*}{$\begin{array}{c}\text { Herbaceous } \\
\text { yield }\end{array}$} & \\
\hline & & & Large trees & Small trees & Shrubs & & & \\
\hline Site 1 & No/ha & & & & & & & $\mathrm{kg} / \mathrm{ha}$ \\
\hline 1 & 865 & 0.68 & 0.23 & 0.09 & 0 & 0 & 0 & 540 \\
\hline 2 & 990 & 0.72 & 0.21 & 0.07 & 0 & 0 & 0 & 860 \\
\hline 3 & 630 & 0.78 & 0.09 & 0.13 & 1.0 & 1.0 & 1.0 & 4370 \\
\hline 4 & 190 & 0.53 & 0.11 & 0.36 & 1.0 & 1.0 & 1.0 & 3400 \\
\hline 5 & 310 & 0.54 & 0.15 & 0.31 & 0.2 & 0.2 & 0.3 & 1030 \\
\hline 6 & 175 & 0.58 & 0.11 & 0.31 & 0 & 0 & 1.0 & 2860 \\
\hline 7 & 215 & 0.58 & 0.11 & 0.31 & 0.8 & 0.8 & 0.8 & 1890 \\
\hline 8 & 150 & 0.41 & 0.14 & 0.45 & 0.5 & 0.5 & 0.5 & 2210 \\
\hline 9 & 615 & 0.67 & 0.21 & 0.12 & 1.0 & 1.0 & 0 & 860 \\
\hline 10 & 0 & na ${ }^{1}$ & na & na & na & na & na & 2500 \\
\hline \multicolumn{9}{|c|}{ Site 2 (no trees killed at this site) } \\
\hline 1 & 410 & 0.55 & 0.35 & 0.10 & & & & 450 \\
\hline 2 & 390 & 0.45 & 0.45 & 0.10 & & & & 480 \\
\hline 3 & 175 & 0.50 & 0.45 & 0.05 & & & & 560 \\
\hline 4 & 55 & 0.60 & 0.40 & 0.00 & & & & 950 \\
\hline 5 & 25 & 0.90 & 0.10 & 0.00 & & & & 1400 \\
\hline .6 & 0 & na & na & na & & & & 1675 \\
\hline \multicolumn{9}{|c|}{ Site 3 (no trees killed at this site) } \\
\hline 1 & 135 & 0.59 & 0.21 & 0.20 & & & & 1480 \\
\hline 2 & 235 & 0.51 & 0.49 & 0.00 & & & & 650 \\
\hline 3 & 120 & 0.68 & 0.32 & 0.00 & & & & 950 \\
\hline 4 & 330 & 0.31 & 0.30 & 0.39 & & & & 900 \\
\hline 5 & 170 & 0.57 & 0.40 & 0.13 & & & & 1350 \\
\hline 6 & 100 & 0.18 & 0.20 & 0.62 & & & & 3100 \\
\hline 7 & 0 & na & na & na & & & & 3350 \\
\hline
\end{tabular}

'not applicable as no trees present in the interspaces

Table 4. Total density and size class composition of woody plants (before and after treatment) in mesquite sites near Alice, Texas.

\begin{tabular}{|c|c|c|c|c|c|}
\hline \multirow[b]{2}{*}{$\begin{array}{l}\text { Cover } \\
\%\end{array}$} & \multirow[b]{2}{*}{$\begin{array}{l}\text { Density } \\
\text { (no/ha) }\end{array}$} & \multicolumn{3}{|c|}{ Proportion of } & \multirow{2}{*}{$\begin{array}{c}\text { Yield } \\
(\mathrm{kg} / \mathrm{ha}) \\
(\mathrm{kg} / \mathrm{ha})\end{array}$} \\
\hline & & $\begin{array}{l}\text { Mature } \\
\text { clusters }\end{array}$ & $\begin{array}{l}\text { Developing } \\
\text { clusters }\end{array}$ & $\begin{array}{l}\text { Pioneer } \\
\text { clusters }\end{array}$ & \\
\hline \multicolumn{6}{|c|}{ Site 1-Undisturbed } \\
\hline $\mathbf{0}$ & 0 & nal & na & na & 1700 \\
\hline 5 & 160 & & & 1.00 & 1600 \\
\hline 15 & 95 & 0.11 & 0.89 & & 1450 \\
\hline 35 & 70 & 1.00 & & & 1200 \\
\hline 40 & 550 & & 0.45 & 0.55 & 1210 \\
\hline 45 & 370 & 0.14 & 0.86 & & 1110 \\
\hline 50 & 160 & 0.50 & 0.50 & & 975 \\
\hline \multicolumn{6}{|c|}{ Site 2 -Herbicide treated } \\
\hline 0 & 0 & na & na & na & 1500 \\
\hline 5 & 40 & & 1.00 & & 1620 \\
\hline 15 & 210 & 0.05 & 0.19 & 0.76 & 1590 \\
\hline 20 & 100 & 0.20 & 0.80 & & 1910 \\
\hline 40 & 290 & 0.17 & 0.28 & 0.55 & 2350 \\
\hline 50 & 370 & 0.14 & 0.43 & 0.43 & 2710 \\
\hline 55 & 280 & 0.29 & 0.14 & 0.57 & 2840 \\
\hline
\end{tabular}

na' not applicable as no trees present in interspaces

increase but $C_{i(t o t a l)}$ decreases such that $C_{i(t o t a l)}<<1$, giving $N_{i}<1$. Thus yield initially increases above yield in the open but herbaceous yield becomes much less than yield in the open at high tree density.

\section{Individual Tree Effects Versus Community Level Effects}

In some cases, isolated trees appear to have no influence on the herbaceous standing crop in and around their canopy $\left(\mathrm{N}_{\mathrm{i}}=1\right)$. This can arise because there is little competition or stimulation (Fig. 6 a,b), or it may arise because strong $\mathrm{C}$ and $\mathrm{S}$ forces are excactly balanced $\left(\mathrm{C}_{\mathrm{i}}^{*} \mathrm{~S}_{\mathrm{i}}=1\right.$, Fig. $\left.6 \mathrm{c}, \mathrm{d}\right)$. However, at the community level, herbaceous standing crop declines, especially at high tree densities. Simulations were conducted using the 4 situations in Figure 6 to determine the community level responses of varying the magnitude of $S$ and $C$ effects (by altering $S_{0}$ and $C_{0}$ ) as well as varying the distance from the tree that stimulation and competitive effects were acting (by altering $r_{s}$ and $r_{c}$ ).

Community level responses ranged from a slight linear decline to a rapid exponential decline in simulated herbaceous production as tree density increased (Fig. 7). Smaller $C_{0}$ and $S_{0}$ values and lower $r_{c}$ and $r_{s}$ values result in less tree influence on herbaceous production at the community level. Where strong competition and stimulation acted at larger distances from the tree and exactly balanced at an individual tree level, the community level response showed a rapid decline in herbaceous standing crop as tree density increased (line c).

The range of curves thus produced (Fig. 5) encompasses the variation reported in the literature, indicating that all reported relationships can be interpreted within the framework of differing relative "strengths" of the $\mathrm{S}$ and $\mathrm{C}$ counteracting forces. Despite the divergent relationships observed, the same underlying relationships can be used to interpret these.

\section{Discussion}

This empirical simulation model can reproduce the range of observed relationships between woody and herbaceous lifeforms present in the literature (see Figs. 5 and 7). These simulated trends depend upon the relative magnitudes of stimulatory and competitive effects of trees on herbaceous understory.

Of particular interest is the ability of the model to predict the initial enhancement of herbaceous productivity at low tree densities and the decreased productivity at high densities within the same vegetation complex (Scifres et al. 1982). This arises because the stimulation effect of trees reaches a maximum $\left(S_{\max }\right)$ at some density, yet the competitive effects continue to increase with tree 
(a)
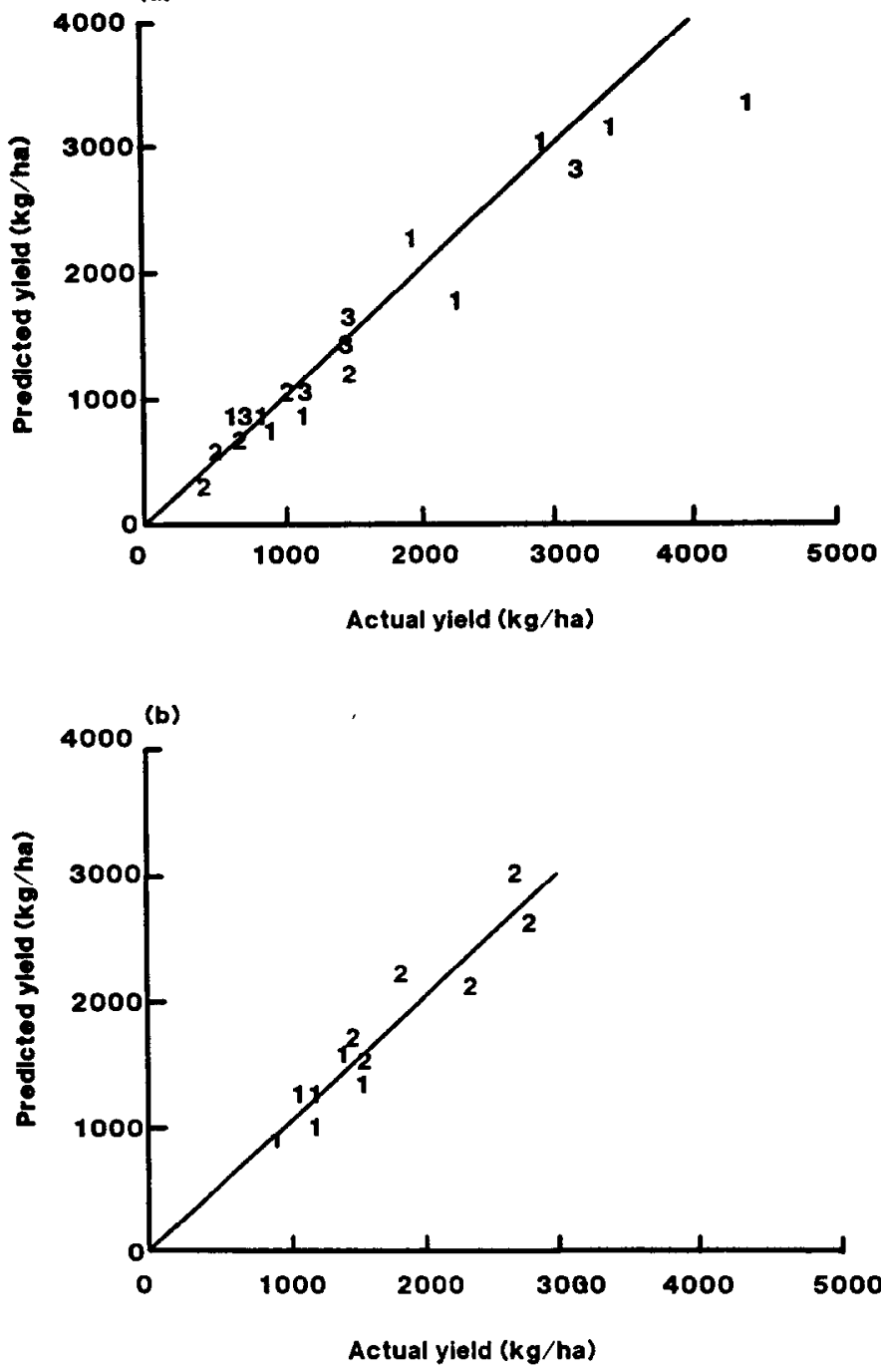

Fig. 3. Actual and simulated herbaceous yield for (a) 3 eucalypt sites near Rockhampton, Australia; and (b) 2 mesquite sites near Alice, Texas. Numbers are site numbers from Tables 3 and 4 and the line is 1:1 line.

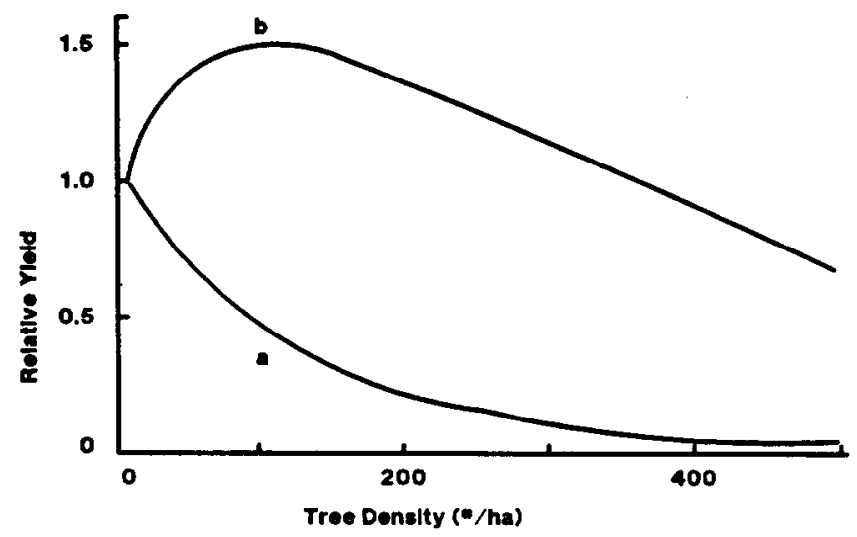

Fig. 5. The herbaceous yield (relative to that in open areas) in simulated tree communities in which isolated trees had (a) net competition; and (b) net stimulation. (See Fig. 4 for the corresponding index patterns around individual trees).

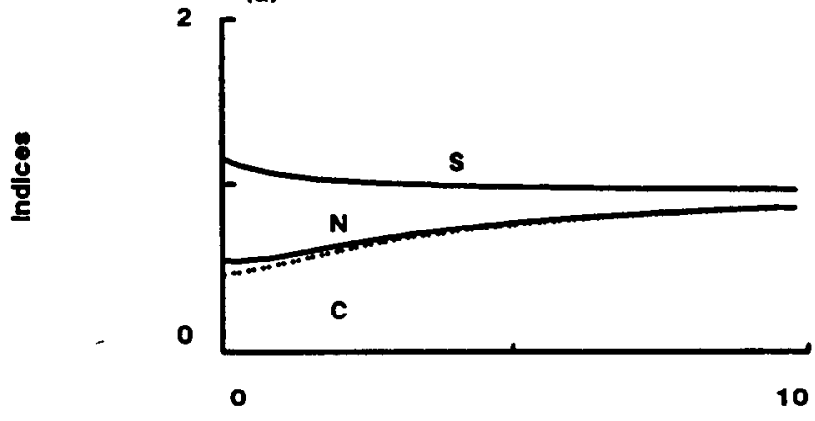

음

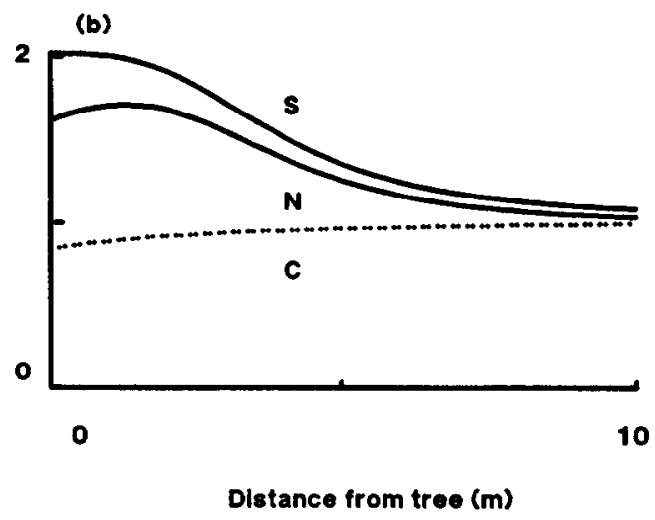

Fig. 4. The stimulation (S), competition (C), and net $(N)$ indices with increasing distance from tree showing (a) net competition; and (b) net stimulation of herbaceous understory around isolated trees. (See Fig. 5 for simulated community level responses corresponding to these individual tree patterns).
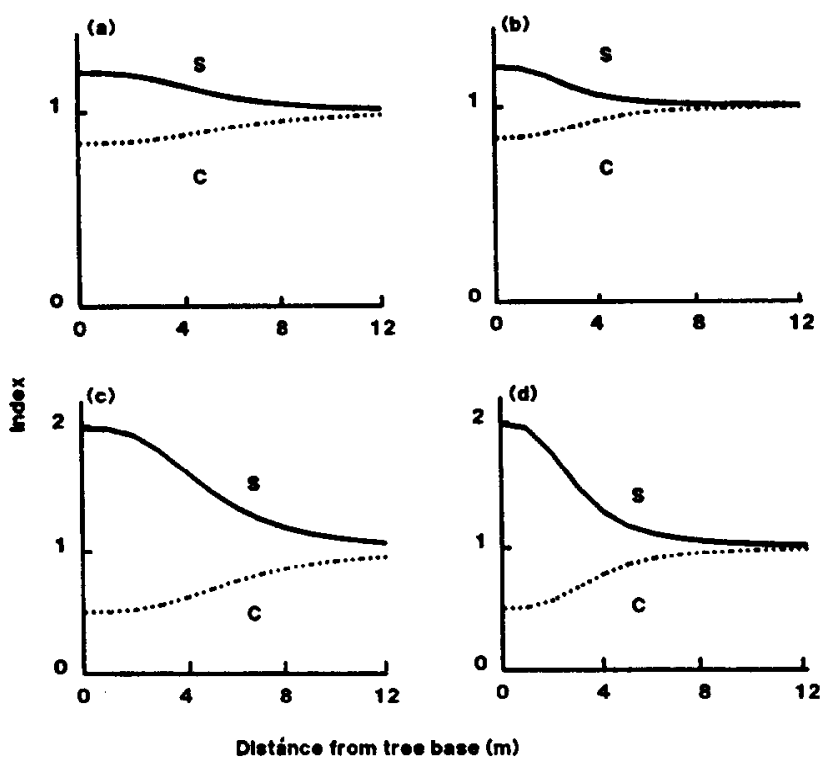

Fig. 6. A range of stimulation (S) and competition (C) indices that give rise to no net effect of individual trees on herbaceous understory. These can arise from (a) small effect operating at long distances from the tree; (b) small effect operating at short distances from the tree; (c) large effect operating at long distances from the tree; and (d) large effect operating at short distances from the tree. (See Fig. 7 for simulated community level responses corresponding to these individual tree patterns). 


\section{Literature Cited}

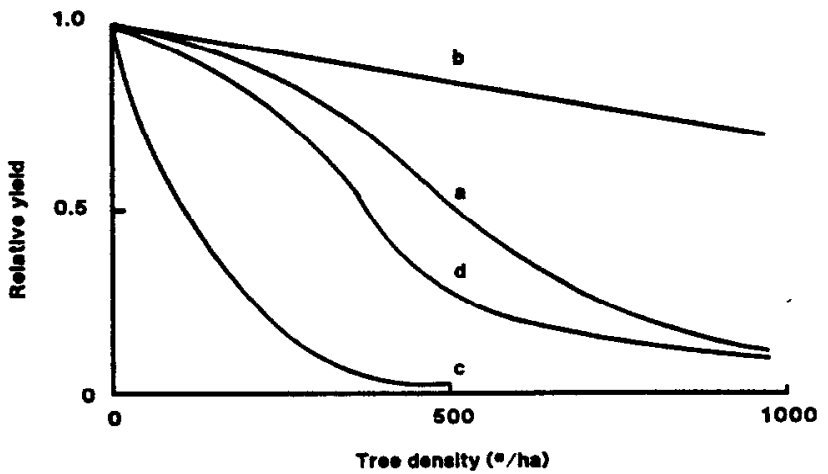

Fig. 7. The herbaceous yield (relative to that in the open) with increasing tree density when individual trees have no net effect on the herbaceous understory. See Fig. 6 for the corresponding Index patterns around individual trees.

density $S_{\max }$ is determined by the genetic potential of the species present and the resources available. It will vary among communities and between years for the same community.

Net stimulation of herbaceous production under tree canopies is most often associated with leguminous shrubs, especially Acacia (Scifres et al. 1982, Teague 1984). This is generally assumed to be related to elevated nutrient status under canopies, although shading by itself is known to increase herbaceous yield in some cases (Wilson et al. 1986). In Australia, the elevated nutrient status under trees (e.g., Ebersohn and Lucas 1965, Dowling et al. 1986) generally does not increase herbaceous productivity at the community level (Walker et al. 1972, Beale 1973, Walker et al. 1986a, Scanlan and Burrows 1990) although Christie (1975) is an exception. This further emphasizes that observations in the field are the net effects of both stimulation and competition.

The model as presented is static and unifies research work that apparently gave divergent results. The necessary changes to make this a dynamic representation of the effect of woody plants on herbaceous productivity are being developed by making stimulation and competition parameters (in Equations 3 and 4) time dependent. Such a dynamic model would allow economic evaluation of many management strategies ranging from agroforestry and fodder-tree systems to tree clearing systems. The basic requirement of these evaluations is to link the cost of development to the period of response (for clearing strategies) and to the time for development to impact production (for agroforestry and fodder tree systems).
Archer, S., C.J. Scifres, C.R. Bassham, and R. Maggio. 1988. Autogenic succession in a subtropical savanna: Rates dynamics and processes in the conversion of a grassland to a thorn woodland. Ecol. Monogr. 58:111-127.

Beale, I.F. 1973. Tree density effects on yields of herbage and tree components in south west Queenlands mulga (Acacia aneura) scrub. Trop. Grassl. 7:135-142.

Christie, E.K. 1975. A note on the significance of Eucalyptus populnea for buffel grass production infertile semi-arid rangelands. Trop. Grassl. 9:243-246.

Clary, W.P. 1975. Range management and its ecological basis in the ponderosa pine type in Arizona: the status of our knowledge. USDA Forest Serv. Res. Paper RM-158.

Dowling, A.J., A.A. Webb, and J.C. Scanlan. 1986. Surface soil chemical and physical patterns in a brigalow-Dawson gum forest, central Queensland. Aust. J. Ecol. 11:155-162.

Ebersohn, J.P., and P. Lucas. 1965. Trees and soil nutrients in southwestern Queensland. Queensl. J. Agr. Anim. Sci. 22:432-435.

Scanlan, J.C., and W.H. Burrows. 1990. Woody overstory impact on herbaceous understory in Eucalypus spp., communities in central Queensland. Aust. J. Ecol. 15:191-197.

Scifres, C.J., and B.H. Koerth. 1987. Climate soils and vegetation of the La Copita Research Area. Texas Agr. Exp. Sta. Rep. MP-1626. College Station, Tex.

Scifres, C.J., J.L. Mutz, R.E. Whitson, and D.L. Drawe. 1982. Interrelationships of huisache canopy cover with range forage on the coastal prairie. J. Range Manage. 35:558-562.

Teague, W.R. 1984. The management of thornveld. Dohne Agr. 6:21-23.

Tiedemann, A.R., and J.O. Klemmedson. 1986. Long-term effects of mesquite removal on soil characteristics 1 . Nutrients and bulk density. Soil Sci. Soc. Amer. J. 50:472-480.

Tothill, J.C., J.N.G. Hargreaves, and R.M. Jones. 1978. BOTANAL-A comprehensive sampling and computing procedure for estimating yield and composition. 1. Field sampling. CSIRO Trop. Agron. Tech. Mem. 8, Brisbane.

United States Department of Agriculture. 1975. Soil Survey of Jim Wells County, Texas. USDA.

Walker, J., R.M. Moore, and J.A. Robertson. 1972. Herbage response to tree and shrub thinning in Eucalyptus shrub woodlands. Aust. J. Agr. Res. 23:405-410.

Walker, J., J.A. Robertson, L.K. Penridge, and P.J.H. Sharpe. 1986a. Herbage response to tree thinning in a Eucalyptus crebra woodland. Aust. J. Ecol. 11:135-140.

Walker, J., P.J. Sharpe, L.K. Penridge, and H. Wu. 1986b. Competitive interactions between individuals of different size: the concept of ecological fields. CSIRO. Div. Water Land Res. Tech. Mem. 86/11, Canberra.

Weston, E.J., J. Harbison, J.K. Leslie, K.M. Rosenthal, and R.J. Mayer. 1981. Assessment of the agricultural and pastoral potential of Queensland. Queensl. Dept. Prim. Ind., Brisbane.

Wilson, J.R., V.R. Catchpoole, and K.L. Weier. 1986. Stimulation of growth and nitrogen uptake by shading a rundown green panic pasture on brigalow clay soil. Trop. Grassl. 20:134-143.

Wu, H., P.J.H. Sharpe, J. Walker, and L.K. Penridge. 1985. Ecological field theory: a spatial analysis of resource interference among plants. Ecol. Mod. 29:215-243.

Wu, H., K.W.J. Malafant, L.K. Penridge, P.J.H. Sharpe, and J. Walker. 1987. Simulation of two-dimensional point patterns: application of a lattice framework approach. Ecol. Mod. 38:299-308. 